\title{
Bionomics of Mussidia nigrivenella (Lepidoptera: Pyralidae) on three host plants
}

\author{
M. Sétamou ${ }^{1,2^{*}}$, F. Schulthess ${ }^{1}$, N.A. Bosque-Pérez ${ }^{3}$, \\ H-M. Poehling ${ }^{2}$ and C. Borgemeister ${ }^{2}$ \\ ${ }^{1}$ International Institute of Tropical Agriculture, Plant Health Management \\ Division, 08 BP 0932 Tri Postal, Cotonou, Republic of Benin, West Africa: \\ ${ }^{2}$ Institute of Plant Diseases and Plant Protection, University of Hannover, \\ Herrenhäuser Str. 2, 30419 Hannover, Germany: ${ }^{3}$ Department of Plant, \\ Soil, and Entomological Sciences, University of Idaho, Moscow, Idaho \\ 83844-2339, USA
}

\begin{abstract}
Life table studies of Mussidia nigrivenella Ragonot, a pest of maize in Benin, showed that host plant species had a significant effect on larval survival and developmental time. The maximum percentage of larvae surviving was recorded on jackbean, Canavalia ensiformis (36\%) and lowest on maize (18\%). Mean developmental time for larvae was longest on maize (19.8 days) and shortest on jackbean (17.2 days). The number of eggs laid was highest for females from larvae fed on jackbean $(\overline{\mathrm{x}}=176)$, followed by velvetbean, Mucuna pruriens $(\overline{\mathrm{x}}=143)$, and lowest for females where larvae had fed on maize $(\bar{x}=127)$. Longevity of ovipositing females was higher on jackbean (5.4 days) than of those from any other host plants. According to the growth index and life table statistics, jackbean was the most suitable host plant, followed by velvetbean, and maize, the least suitable. Thus, jackbeans should be recommended for use in mass rearing programmes of M. nigrivenella, e.g. as a host for parasitoids in future biological control programmes. Because of the high suitability of jack- and velvetbeans for M. nigrivenella, planting of these increasingly important cover crops should be timed in such a manner that the emergence of female moths from mature pods does not coincide with maize plants in a suitable developmental stage for oviposition and development of young $M$. nigrivenella larvae.
\end{abstract}

\section{Introduction}

The maize cob borer, Mussidia nigrivenella Ragonot (Lepidoptera: Pyralidae), is a commonly occurring pest which occasionally causes serious crop damage on maize (Moyal \& Tran, 1991b; Bosque-Pérez \& Mareck, 1990; Gounou et al., 1994; Sétamou et al., 1998) and cotton (Silvie, 1993) in West Africa. Population densities of M. nigrivenella vary according to the different agro-ecological zones in Benin (Sétamou, 1996). Large populations occur in the

*Fax: +490511762 19205

E-mail: setamou@mbox.ipp.uni-hannover.de
Guinea Savannahs of Benin (Sétamou, 1996), Ghana (Gounou et al., 1994), and Côte d'Ivoire (Moyal, 1988). In addition to maize, Sétamou (1996) identified 16 plant species in Benin on which different life stages of the borer were found. According to Sétamou (1996), the high population densities of M. nigrivenella in the Guinea Savannahs of Benin are due to the abundance and diversity of various host plants. These comprise several economically important tree species, such as Parkia biglobosa (Jacq.) Benth (Mimosaceae) and shea butter, Butyrospermum parkii (G. Don) Kotschy (Sapotaceae) and two new cover crops, velvetbean, Mucuna pruriens DC. (Fabaceae), and jackbean, Canavalia ensiformis (L.) DC. (Fabaceae), introduced to Africa in the last decade. Because of their high nitrogen content, jack- and velvetbeans 
are used to improve and maintain soil fertility and to reduce soil erosion (Vissoh et al., 1998). In addition, their role in controlling weeds, especially Imperata cylindrica (Linnaeus) Raeuschel (Poaceae) is well documented (Vissoh et al., 1998). The grains of these cover crops can also be used as animal fodder and for human consumption, (Udedibie, 1990; OseiBonsu et al., 1996). However, due to the toxicity of the mature seeds of both jack- and velvetbeans, the seeds have to be processed prior to consumption (Udedibie, 1990). Because of the great interest of West African farmers in these new cover crops, it is expected that jack- and velvetbeans will become key components in the farming systems.

Insect development is a key factor in understanding insect ecology. The development of $M$. nigrivenella on maize in the field has been intensively studied (Moyal \& Tran, 1991b; Bosque-Pérez \& Mareck, 1990; Silvie, 1993; Sétamou, 1996). However, little is known about the borer's performance on other host plant species. Some authors have investigated the biology of $M$. nigrivenella in the laboratory, using meridic diets (Bordat \& Renand, 1987; Moyal \& Tran, 1991a; Bolaji \& Bosque-Pérez, 1998). Insects reared on artificial diets may have different feeding preferences to those feeding on natural host plants (Guthrie et al., 1974). Hence, a better understanding of the biology, ecology and behaviour of a species may be gained by rearing insects on natural host plants.

The objective of this study was to determine host plant suitability of maize and jack- and velvetbeans for M.nigrivenella. Studying the performance of M. nigrivenella on jack- and velvetbeans could help to predict the risk these cover crops represent as a source of infestation for the borer in maize crops, and also to suggest appropriate management strategies.

\section{Material and methods \\ Plant material}

Maize, Zea mays L. (Poaceae), was chosen as a host plant to understand the performance of $M$. nigrivenella on maize cobs in the field. The two other host plant species used in this study were jack- and velvetbeans. All plants were grown at the Benin station of the International Institute of Tropical Agriculture (IITA) in Abomey-Calavi, as mono-crops in blocks of one hectare each. The crops were planted twice at a planting density of $80 \mathrm{~cm}$ by $40 \mathrm{~cm}$ for maize, and $80 \mathrm{~cm}$ by $80 \mathrm{~cm}$ for velvet-and jackbeans. The first crops of jack- and velvetbeans were planted in late April 1994. Maize (cv. TZSR [Tropical Zea Streak Resistant; an improved 4-month IITA variety]) was first planted 45 days later, to ensure a synchronization of the maturity of cobs and pods of each host plant species, since $M$. nigrivenella larvae feed only on mature cobs and fruits (Sétamou, 1996). NPK fertilizer (15-15-15) was applied to the maize crop at a rate of $200 \mathrm{~kg} \mathrm{ha}^{-1}$ three weeks after planting. Cobs and pods with seeds at the dough stage, i.e. completely formed, were used to start the feeding experiment. Mussidia nigrivenella oviposits only on maize during this stage (Whitney, 1970; Moyal \& Tran, 1991b).

\section{Test larvae}

Larvae of M. nigrivenella used in each experiment originated from an IITA stock culture, maintained for two generations on maize cobs. Newly-oviposited eggs were collected and transferred to incubation chambers consisting of clear plastic containers ( $20 \mathrm{~cm}$ long, $12 \mathrm{~cm}$ diameter, 10 $\mathrm{cm}$ high), containing moistened tissue paper at the base. The eggs were placed on the tissue paper and incubated at $26 \pm 2{ }^{\circ} \mathrm{C}$ under $12: 12$ (L:D) photoperiod for approximately five days. On the sixth day, newly emerged larvae (c. one day-old) were transferred onto pieces of diet.

\section{Rearing procedures}

Maize cobs with husks and pods of jack- and velvetbeans were harvested and cut into $10 \mathrm{~cm}$ long pieces. Cut pieces were disinfected in bleach solution (5\%) for 30 min, and rinsed twice with distilled water. Each piece was infested with 25 first instar larvae of $M$. nigrivenella, and the pieces were grouped (four for maize and eight for jack- and velvetbeans) in plastic rearing containers $(14 \mathrm{~cm}$ in height and $11 \mathrm{~cm}$ in diameter). In each experiment, 25 rearing containers were used for maize and ten containers for each of the other two host plants. Five experiments were conducted between 1994 and 1997, with a total initial population of 12,500 larvae on maize, and 10,000 larvae each for jack- and velvetbeans. The containers were covered with plastic mesh and kept under controlled conditions at $26 \pm 2^{\circ} \mathrm{C}, 65 \pm 5 \%$ relative humidity (rh), and a photoperiod of 12:12 (D:L). After 10 days, the diet was renewed for all treatments. As the larvae increased in size, only ten (or fewer) larvae were kept on each plant piece. For those larvae reared on maize and velvetbean, the diet had to be renewed between two and three and three times, respectively. For jackbean, no further diet renewal was needed before pupation. When pupation started, the containers were examined daily and cocoons were collected. Cocoons were kept individually in gelatine capsules for two days, after which the pupae were removed using a pair of scissors. The pupae were sexed and kept in petri dishes until adult emergence. Two pairs of newly emerged adults were selected from each rearing container for the adult longevity and fecundity study. A total of 250 pairs for maize and 100 pairs for jack- and velvetbeans, respectively were used throughout the study. Adults were allowed to mate and oviposit in boxes (clear plastic cylinders, $10 \mathrm{~cm}$ in height and $10 \mathrm{~cm}$ in diameter) and were supplied with a piece of cotton wool soaked in sugar-water placed in a small cup, as food source for the adults. Tissue paper with a rough surface was attached to the inside of the box as an oviposition substrate for females. The viability of eggs laid by females which had emerged from the three tested host plants was studied in each of the five experiments, by incubating 100 randomly selected eggs per host plant treatment.

\section{Data collected}

The percentage of survival of larvae ten and 16 days after infestation, the percentage of pupae formed, and the duration of the larval and pupal stages were recorded. All pupae were sexed, and the sex-ratio was determined for each host plant. The longevity of adults and the fecundity of adult females were recorded. Developmental time for each life stage $(L)$ was computed after $L=n_{i} x_{i} / n_{i}$, where $n_{i}$ is the number of individuals and $x_{i}$ the time required to complete the developmental stage. The viability of eggs, calculated as the proportion of larvae hatching from the incubated eggs, was recorded. Life table statistics were calculated to estimate 
Table 1. Effect of host plants on mean ( \pm SE) survival, growth and developmental time of Mussidia nigrivenella.

\begin{tabular}{|c|c|c|c|c|c|c|c|}
\hline \multirow[t]{2}{*}{ Host plant } & \multirow[t]{2}{*}{$\begin{array}{l}\text { Larval period } \\
\quad \text { (days) }\end{array}$} & \multirow{2}{*}{$\begin{array}{l}\text { Pupae } \\
\text { formed } \\
(\%)\end{array}$} & \multicolumn{2}{|c|}{$\begin{array}{l}\text { Pupal weight } \\
\text { (mg) }\end{array}$} & \multicolumn{2}{|c|}{$\begin{array}{l}\text { Pupal period } \\
\text { (days) }\end{array}$} & \multirow{2}{*}{$\begin{array}{c}\text { Adult } \\
\text { emergences } \\
(\%)\end{array}$} \\
\hline & & & males & females & males & females & \\
\hline Zea mays & $\begin{array}{c}19.7 \pm 0.05 c^{1} \\
(2304)^{2}\end{array}$ & $\begin{array}{c}18.4 \pm 0.6 \mathrm{a} \\
\quad(125)\end{array}$ & $\begin{array}{l}87 \pm 7 \\
(1148)\end{array}$ & $\begin{array}{c}102 \pm 6 \mathrm{a} \\
(1156)\end{array}$ & $\begin{array}{l}10.5 \pm 0.03 \\
\quad(1068)\end{array}$ & $\begin{array}{l}10.4 \pm 0.03 \\
\quad(1080)\end{array}$ & $\begin{array}{l}93.4 \pm 2.1 \\
\quad(125)\end{array}$ \\
\hline Canavalia ensiformis & $\begin{array}{c}17.9 \pm 0.03 \mathrm{a} \\
(3618)\end{array}$ & $\begin{array}{c}36.2 \pm 1.8 \mathrm{c} \\
(50)\end{array}$ & $\begin{array}{l}89 \pm 5 \\
(1715)\end{array}$ & $\begin{array}{c}113 \pm 3 \mathrm{~b} \\
(1903)\end{array}$ & $\begin{array}{c}10.5 \pm 0.02 \\
(1580)\end{array}$ & $\begin{array}{c}10.4 \pm 0.02 \\
\quad(1758)\end{array}$ & $\begin{array}{c}92.2 \pm 2.7 \\
\quad(50)\end{array}$ \\
\hline Mucuna pruriens & $\begin{array}{l}19.2 \pm 0.06 \mathrm{~b} \\
\quad(2820)\end{array}$ & $\begin{array}{c}28.2 \pm 1.4 \mathrm{~b} \\
\quad(50)\end{array}$ & $\begin{array}{l}90 \pm 5 \\
(1416)\end{array}$ & $\begin{array}{c}100 \pm 3 \mathrm{a} \\
(1404)\end{array}$ & $\begin{array}{c}10.4 \pm 0.09 \\
(1330)\end{array}$ & $\begin{array}{c}10.4 \pm 0.03 \\
\quad(1362)\end{array}$ & $\begin{array}{l}94.1 \pm 3.1 \\
\quad(50)\end{array}$ \\
\hline F-value & 476.00 & 71.56 & 0.15 & 1.19 & 0.67 & 0.44 & 1.23 \\
\hline MSE & 5.57 & 84.97 & - & 697.83 & - & - & - \\
\hline df total & 8741 & 224 & 4278 & 4462 & 3977 & 4199 & 224 \\
\hline$P$-value & $<0.001$ & $<0.001$ & ns & $<0.05$ & ns & ns & ns \\
\hline
\end{tabular}

${ }^{1}$ Values in the same column, followed by the same letter, are not significantly different $(P<0.05$; Student Newman Keuls test).

${ }^{2}$ Values in parentheses are number of observations for each treatment.

the growth rates of $M$. nigrivenella on the three host plants (Southwood, 1966). Net reproductive rate $\left(R_{0}\right)$, the growth rate (the intrinsic rate of natural increase $r$ ), the finite capacity of increase $\lambda$, defined as the number of times a population multiplies itself per unit time, the generation time and the doubling time of $M$. nigrivenella were calculated using a jacknife programme (Hulting et al., 1990).

\section{Statistical analysis}

Percent survival, developmental times, weight of pupae, female fecundity and life table parameters were subjected to analysis of variance for the effects of larval host plants. Means were separated using the sequential Student Newman Keuls (SNK) test when significant F-values were obtained $(P<0.05)$ (Zar, 1974). The sex ratio was compared with an assumed 1:1 ratio using the Wilcoxon $\chi^{2}$ test of conformity (Sokal \& Rohlf, 1992). All percentages were arcsin $\delta x$-transformed before analysis, and the results presented as back-transformed data.

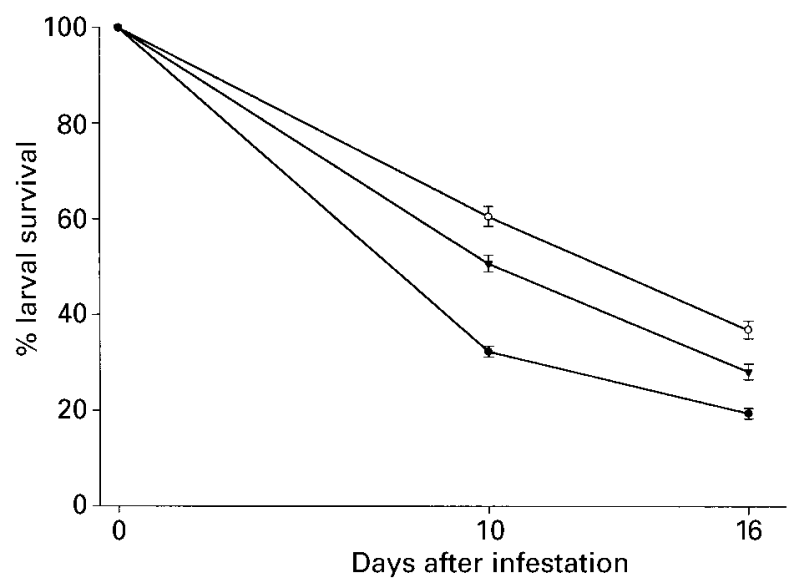

Fig. 1. Effect of host plants on mean larval survival of Mussidia nigrivenella. $\mathrm{N}=125$ for maize $(\bullet)$, and 50 for Canavalia ensiformis (O) and Mucuna pruriens ( $\mathbf{\nabla})$, respectively; error bars are standard errors of the mean.

\section{Results}

The timing of the five independent experiments had no significant effect on any of the variables $(P>0.05)$ and so for each treatment the data were pooled across experiments.

The survival of $M$. nigrivenella larvae was significantly affected by the choice of host plant, resulting in significant differences in the percentage of pupae formed (table 1). Highest survival was found on jackbean and lowest on maize. The effect of host plants on larval mortality was already apparent ten days after infestation (fig. 1). The larval developmental period was also significantly influenced by host plant, and was shortest on jackbean and longest on maize (table 1). Similarly, female pupae were heaviest on jackbean. However, no significant effects of host plant were observed for male pupal weight, duration of pupal development and the proportion of emerged adults (table 1). The percentage of adults emerging from pupae did not vary with sex $(\mathrm{t}=0.62, \mathrm{df}=13, P>0.05)$ and the observed male : female sex ratios on the three host plants (for maize 1: 1.03; for velvetbean 1: 1.02; for jackbean $1: 1.08$ ) did not differ significantly from a $1: 1$ ratio (Wilcoxon $\chi^{2}=0.79$, for maize, $\chi^{2}=0.94$ for velvetbean, and $\chi^{2}=1.04$ for jackbean, $\mathrm{df}=1$, $P>0.05$ for all three host plants).

Jackbeans yielded a significantly higher proportion of egg-laying females and those females laid significantly more eggs than females emerging from larvae reared on the two other host plants (table 2). In addition, the oviposition period of females emerging from larvae fed on jackbean was significantly longer than those reared either on maize or velvetbean (table 2). Adult longevity of males and females was not affected by the host plant species. Oviposition commenced on the day of adult emergence without any preoviposition period (fig. 2). For all three host plants, the peak of egg laying was observed on the second day of the oviposition period and declined thereafter. Although some females were observed to lay eggs for about 10-12 days, in all treatments oviposition lasted for an average of five to six days. Females laid more than $90 \%$ of their eggs during the first three days of the oviposition period. There were no significant differences in the post-ovipositional period between the three host plants (4.1, 4.2 and 3.8 days on maize, velvet- and jackbeans, respectively). The viability of eggs was not influenced by the parental host plants. 


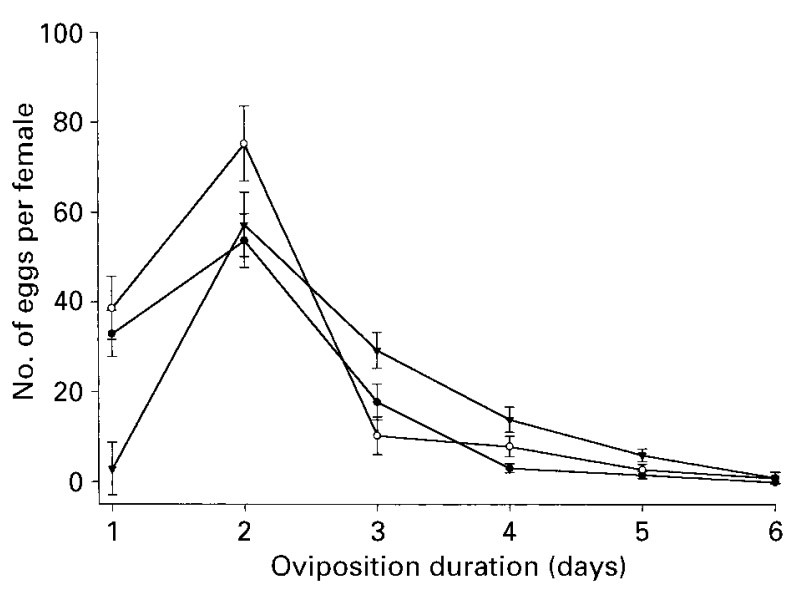

Fig. 2. Effect of host plants on mean female fecundity in Mussidia nigrivenella. $\mathrm{N}=215,93$ and 85 for maize (O), Canavalia ensiformis (O) and Mucuna pruriens ( $\boldsymbol{\nabla})$, respectively; error bars are standard errors of the mean.

More than $95 \%$ of adult mortality of M. nigrivenella occurred during the first eight days of adult life, with peak mortalities on the fifth day for adults emerging from larvae reared on maize and velvetbean, and on the sixth day for jackbean, respectively (fig. 3).

The net reproductive rate, the intrinsic rate of increase, the finite rate of increase, the generation time and the doubling time varied significantly with host plants (table 3 ). The net reproductive rate was highest for females emerging from larvae fed on jackbean $(\mathrm{F}=10.84, \mathrm{df}=2,12, P<0.01$, table 3). Generation time was shortest for larvae fed on jackbean $(\mathrm{F}=133.48, \mathrm{df}=2,12, P<0.01)$, with approximately 35.5 days from egg stage to adult mortality (table 3). The generation time on maize and velvetbean was similar (between 37 and 38 days). The host plant species had a significant effect on the intrinsic rate of increase and the doubling time (table 3). Moths emerging from larvae reared on jackbean produced the highest number of individuals/female/day, followed by those fed on velvetbean. The lowest daily progeny production per female was recorded for moths emerging from larvae reared on maize (table 3). The finite rate of increase was significantly higher on jackbean compared to maize. Doubling time for moths emerging from larvae fed on jackbean was $30 \%$ and $19 \%$ shorter than on maize and on velvetbean, respectively. The growth index on jackbean was about twice as high as on maize and substantially higher than that on velvetbean. The total progeny was significantly higher on jackbean compared to the two other host plants (table 3).

\section{Discussion}

Survivorship of larvae of M. nigrivenella on maize was consistent with Slobodkin's type IV survival curve (Southwood, 1966), indicating that population decrease mainly occurred during the early instars. The most likely explanation is that the extent and thickness of the maize husk covering adversely affected the establishment of first instar larvae on the cob. Characteristics of husk cover of maize have been reported to have a substantial effect on infestation levels of the maize weevil Sitophilus zeamais (Motschulsky) (Coleoptera: Curculionidae) (Kossou et al., 1993) and the larger grain borer Prostephanus truncatus (Horn) (Coleoptera: Bostrichidae) (Meikle et al., 1998). Moyal \& Tran (1991a) observed 90\% mortality of the first two instars of $M$. nigrivenella in maize in the field. Once the larvae have successfully established in the cobs, $M$. nigrivenella seems to be protected by the husks from any adverse effect, and as a consequence they suffer only low levels of mortality in later instars. Also, maize grains are nutritious and have a high water content which can reduce the mortality of larvae after their establishment on maize cobs (N.A. Bosque-Pérez, unpublished data). Moyal \& Tran (1991a) observed less than 10\% mortality of larvae for late instars on meridic diets in the laboratory. Thus, establishment of larvae in the cobs may be one of the most important factors determining the number of larvae found per cob in maize fields. The survival curve for M. nigrivenella on jack- and velvetbeans was similar to a Slobodkin's type III survival curve of constant mortality over time (Southwood, 1966). In maize, only the grains were used as a food source by $M$. nigrivenella larvae, whereas on jackbean, larvae were found feeding on every part of the pods and on

Table 2. Effect of host plants on mean $( \pm$ SE) adult longevity, fecundity, and egg viability of Mussidia nigrivenella.

\begin{tabular}{|c|c|c|c|c|c|c|}
\hline \multirow[t]{2}{*}{ Host plant } & \multirow{2}{*}{$\begin{array}{c}\% \text { Adult } \\
\text { females } \\
\text { laying eggs }\end{array}$} & \multirow{2}{*}{$\begin{array}{l}\text { No. eggs } \\
\text { per } \\
\text { female }\end{array}$} & \multirow[t]{2}{*}{$\begin{array}{l}\% \text { eggs } \\
\text { fertile }\end{array}$} & \multirow{2}{*}{$\begin{array}{l}\text { Oviposition } \\
\text { period } \\
\text { (days) }\end{array}$} & \multicolumn{2}{|c|}{$\begin{array}{l}\text { Adult longevity } \\
\text { (days) }\end{array}$} \\
\hline & & & & & males & females \\
\hline Zea mays & $\begin{array}{c}86.1 \pm 3.4 \mathrm{a}^{1} \\
(250)^{2}\end{array}$ & $\begin{array}{l}126 \pm 16 \mathrm{a} \\
\quad(215)\end{array}$ & $\begin{array}{l}29.4 \pm 1.0 \\
\quad(500)\end{array}$ & $\begin{array}{l}4.7 \pm 0.2 \mathrm{a} \\
\quad(215)\end{array}$ & $\begin{array}{l}6.9 \pm 1.2 \\
\quad(250)\end{array}$ & $\begin{array}{c}7.8 \pm 1.6 \\
(250)\end{array}$ \\
\hline Canavalia ensiformis & $\begin{array}{c}93.2 \pm 3.1 \mathrm{~b} \\
(100)\end{array}$ & $\begin{array}{c}172 \pm 13 b \\
(93)\end{array}$ & $\begin{array}{l}32.4 \pm 1.5 \\
\quad(500)\end{array}$ & $\begin{array}{c}5.4 \pm 0.2 b \\
(93)\end{array}$ & $\begin{array}{c}7.3 \pm 1.2 \\
(100)\end{array}$ & $\begin{array}{c}8.2 \pm 1.1 \\
\quad(100)\end{array}$ \\
\hline Mucuna pruriens & $\begin{array}{c}84.7 \pm 3.7 \mathrm{a} \\
(100)\end{array}$ & $\begin{array}{c}123 \pm 11 \mathrm{a} \\
(85)\end{array}$ & $\begin{array}{c}32.8 \pm 1.6 \\
\quad(500)\end{array}$ & $\begin{array}{c}4.9 \pm 0.2 \mathrm{a} \\
(85)\end{array}$ & $\begin{array}{l}7.2 \pm 1.4 \\
(100)\end{array}$ & $\begin{array}{c}8.5 \pm 1.4 \\
(100)\end{array}$ \\
\hline F-value & 3.81 & 5.03 & 2.64 & 3.27 & 1.98 & 2.04 \\
\hline MSE & 246.7 & 674.4 & - & 1.31 & - & - \\
\hline df total & 449 & 392 & 1499 & 392 & 449 & 449 \\
\hline$P$-value & $<0.05$ & $<0.01$ & ns & $<0.05$ & ns & ns \\
\hline
\end{tabular}

${ }^{1}$ Values in the same column, followed by the same letter, are not significantly different $(P<0.05$; Student Newman Keuls test).

${ }^{2}$ Values in parentheses are number of observations for each treatment. 
Table 3. Effect of host plants on life table parameters ( \pm SE) and growth index of Mussidia nigrivenella.

\begin{tabular}{lccccccc}
\hline Host plant & $\mathrm{R}_{0}{ }^{1}$ & $\mathrm{r}$ & $\lambda$ & $\mathrm{T}$ & $\mathrm{DT}$ & Total progeny & $\mathrm{GI}^{2}$ \\
\hline Zea mays & $10.1 \pm 0.4 \mathrm{a}^{3}$ & $0.071 \pm 0.001 \mathrm{a}$ & $1.07 \pm 0.002 \mathrm{a}$ & $37.5 \pm 0.2 \mathrm{c}$ & $9.8 \pm 0.2 \mathrm{c}$ & $20.3 \pm 0.8 \mathrm{a}$ & 0.56 \\
Canavalia ensiformis & $23.8 \pm 3.2 \mathrm{~b}$ & $0.104 \pm 0.005 \mathrm{~b}$ & $1.11 \pm 0.006 \mathrm{~b}$ & $35.5 \pm 0.4 \mathrm{a}$ & $6.8 \pm 0.3 \mathrm{a}$ & $47.3 \pm 6.3 \mathrm{~b}$ & 1.17 \\
Mucuna pruriens & $14.9 \pm 1.8 \mathrm{a}$ & $0.084 \pm 0.004 \mathrm{a}$ & $1.09 \pm 0.006 \mathrm{a}$ & $36.9 \pm 0.1 \mathrm{~b}$ & $8.4 \pm 0.4 \mathrm{~b}$ & $29.7 \pm 3.6 \mathrm{a}$ & 0.88 \\
F-value & 10.84 & 19.30 & 11.83 & 133.48 & 20.64 & 10.50 & \\
MSE & 22.49 & 0.0001 & 0.0001 & 0.040 & 0.54 & 89.65 & \\
df total & 14 & 14 & 14 & 14 & 14 & 14 & \\
$P$-value & 0.002 & $<0.001$ & $<0.001$ & $<0.001$ & $<0.001$ & $<0.002$ &
\end{tabular}

${ }^{1} \mathrm{R}_{0}$, net reproductive rate; $\mathrm{r}$, intrinsic rate of increase; $\lambda$, finite rate of increase; $\mathrm{T}$, generation time in days; DT, doubling time in days calculated using the jacknife programme described by Hultin et al. (1990).

${ }^{2} \mathrm{GI}$, growth index, computed as the ratio between the percentage of adults emerged and the duration of the immature period (larval and pupal) (Ramasubramanian \& Babu, 1989).

${ }^{3}$ Means followed by the same letter, in the same column are not significantly different $(P<0.05$, Student Newman Keuls sequential test).

velvetbean, even on the valves. Thus on jack- and velvetbeans, early instars did not starve before penetration into the pods and as a result, had lower mortality rates than on maize. However, moderately high mortality of larvae was observed on jack- and velvetbeans, possibly due to the handling of the insects during the experimentation.

The observed differences in survivorship of larvae on the three tested host plants in this study may explain the varying infestation levels of $M$. nigrivenella observed in the field at the IITA-Benin station, where considerably more M. nigrivenella borers occur on jack- and velvetbeans than on maize cobs (M. Sétamou, unpublished data). Our mortality levels were much higher than the $5 \%$ and $24 \%$ mortalities recorded by Bordat \& Renand (1987) and Bolaji \& BosquePérez (1998) respectively, using artificial diets. Artificial diets, however, tend to have higher vitamin and amino acid contents resulting in lower mortality and higher fecundity (Vanderzant, 1974).

The prolonged larval period of M. nigrivenella on maize may have been due to the quality of the diet. Numerous studies have shown that diet quality has an important impact on insect developmental time. Bolaji \& Bosque-Pérez (1998) observed a reduction in developmental time of M. nigrivenella when larvae were reared on a jackbean-based diet compared to maize-based diets. In most cases, the duration of larval period of insects is inversely related to the nitrogen level of the food source (Al-Zubaidi \& Capinera, 1983). Duration of the larval period in Sesamia calamistis Hampson (Lepidoptera: Noctuidae) was shorter when the larvae were reared on maize stems supplied with additional nitrogen (Sétamou et al., 1993). Both jack- and velvetbeans are leguminous crops and therefore contain high levels of protein (Duke, 1981). Moreover, in this study female pupae originating from larvae reared on jackbean were the heaviest, probably as a result of better food quality for the larvae.

The total developmental time of $M$. nigrivenella recorded in the present study and the mean adult life span were comparable to those reported by Bolaji \& Bosque-Pérez (1998), though these authors conducted their studies using a meridic diet. The mean number of eggs laid per female was higher on jackbean compared to maize and velvetbean. Differences in the fecundity of $M$. nigrivenella according to the diet used, were also reported by Bolaji \& Bosque-Pérez (1998). These authors observed that diets containing flour from leguminous seeds yielded females that laid significantly more eggs than females originating from larvae fed on maize-flour based diets only. A larval diet rich in protein content often results in increased fecundity of many Lepidoptera, e.g. in Spodoptera litura (Fabricius) (Lepidoptera: Noctuidae) (Sankeperumal et al., 1989). Applying nitrogenous fertilizer to maize plants increased the number of eggs laid by S. calamistis (Sétamou et al., 1993). Egg viability in this study (29-33\%) was lower than that observed by Bolaji \& Bosque-Pérez (1998) (72-90\%), but comparable to that reported by Moyal \& Tran (1991a) (25-30\%). Adding proteins to the larval diet of Apomyelois ceratoniae Zeller (Lepidoptera: Pyralidae) improved fecundity and egg fertility by $30 \%$ (Al-Izzi et al., 1988). The diet used by Bolaji \& Bosque-Pérez (1998) for rearing M. nigrivenella contained vitamins and was therefore most likely a better food source than the host plant materials used in the present study.

The effect of host plants on M. nigrivenella are best observed by comparing life table statistics. The growth index (Ramasubramanian \& Babu, 1989) for insects reared on maize was lower than that observed for insects reared on jack- and velvetbeans, whereas the generation time was longest on maize. On jackbean, the increase in population size of $M$. nigrivenella per generation was more than double that observed on maize. Thus, it can be concluded that

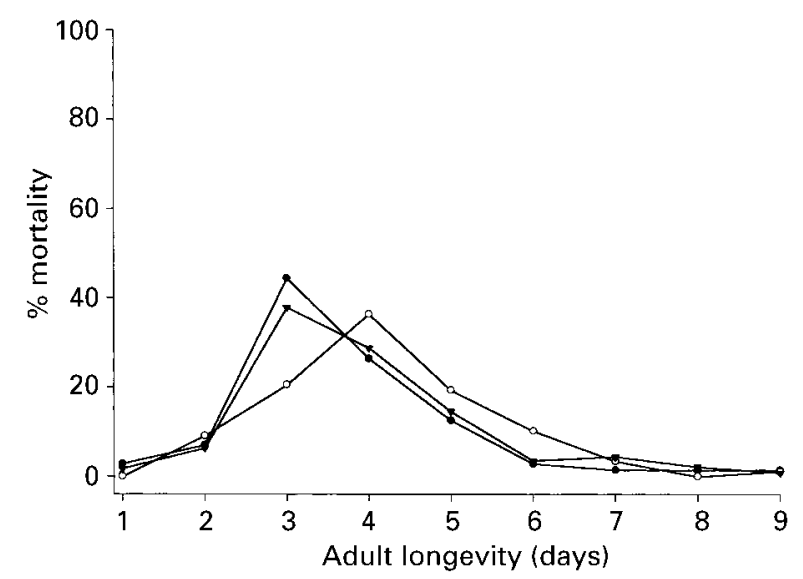

Fig. 3. Effect of host plants on mortality pattern of adult Mussidia nigrivenella. $\mathrm{N}=500$ for maize $(\bullet)$ and 200 for Canavalia ensiformis $(\bigcirc)$ and Mucuna pruriens $(\boldsymbol{\nabla})$, respectively. 
maize cobs were nutritionally inferior to the pods of jackand velvetbeans.

Overall, jackbean proved to be the most suitable host plant for M. nigrivenella. Hence, for mass rearing of $M$. nigrivenella, e.g. as host for parasitoids in a biological control programme, jackbean would seem to be an ideal candidate. Moreover, jackbean offers the advantage of only requiring to change the diet once during the larval development, whereas several food changes are required when rearing M. nigrivenella larvae on other host plants.

The present work is part of a larger study on the role of various host plants in the population dynamics of M. nigrivenella in West Africa. The greater suitability of jackand velvetbeans compared with maize might have direct effects on the population dynamics of M. nigrivenella, especially considering the high adoption rate of these cover crops by West African farmers. Velvet- and jackbeans can host large populations of M. nigrivenella and thereby constitute a viable infestation source for maize. In Benin, generally, M. nigrivenella densities in maize fields do not exceed two to three borers per cob (Shanower et al., 1991; Sétamou, 1996). However, in a field experiment conducted at the IITA station in Benin, M. nigrivenella densities in a maize field close to fields of velvet- and jackbeans were as high as four to five borers per maize cob at harvest (M. Sétamou, unpublished data). Hence, it is suggested that farming practices should be managed in such a way that the fruiting periods of jack- and velvetbeans do not precede that of maize, thereby avoiding $M$. nigrivenella populations shifting from cover crops to maize. However, in areas with two maize growing seasons per year (i.e. southern Benin), harvesting the pods of jack- and velvetbeans at maturity could greatly reduce the risk of $M$. nigrivenella infestations in maize.

\section{Acknowledgements}

We thank S. Gounou, P. Gbelissanon, R. Codjovi and E. Hountohotegbe for their technical assistance in various phases of this research, and Dr D. Scholz for critically reviewing the manuscript. The research was supported by the IITA's Maize Health Management Project funded by the International Fund of Agricultural Development (IFAD). M. Sétamou was supported by a grant of the German Academic Exchange Service (DAAD).

\section{References}

Al-Izzi, M.A.J., Al-Malikky, S.K. \& Jabbo, N.F. (1988) Effects of supplemental dietary L-lysine and soybean flour on growth and fertility of Ectomyelois ceratoniae Zeller (Lepidoptera: Pyralidae). Journal of Economic Entomology 81, 970-972.

Al-Zubaidi, F.S. \& Capinera, J.L. (1983) Utilization of food and nitrogen by the beet armyworm, Spodoptera exigua (Hubner) (Lepidoptera: Noctuidae), in relation to food type and dietary nitrogen levels. Environmental Entomology 13, 1604-1608.

Bolaji, O.O. \& Bosque-Pérez, N.A. (1998) Life history and massrearing of Mussidia nigrivenella Ragonot (Lepidoptera: Pyralidae) on artificial diets. African Entomology 6, 101-110.

Bordat, D. \& Renand, M. (1987) Mussidia nigrivenella Ragonot (Lepidoptera, Pyralidae): mise au point d'un élevage de masse sur milieux nutritifs artificiels. L'Agronomie Tropicale 42, 139-144.
Bosque-Pérez, N.A. \& Mareck, J.H. (1990) Distribution and species composition of lepidopterous maize borers in southern Nigeria. Bulletin of Entomological Research 80, 363-368.

Duke, J.A. (1981) Handbook of legumes of world economic importance. 337 pp. New York, USA, Plenum Press.

Gounou, S., Schulthess, F., Shanower T., Hammond, W.H.O., Braima, H., Cudjoe, A.R., Adjakloe, R., Antwi, K.K. \& Olaleye, I. (1994) Stem and cob borers of maize in Ghana. Plant Health Management Research Monograph 4. International Institute of Tropical Agriculture, Ibadan, Nigeria.

Guthrie, W.D., Rhone, Y.S., Cox, D.F. \& Reed, G.L. (1974) European corn borer: virulence on corn plants of larvae reared for different generations on a meridic diet. Journal of Economic Entomology 67, 605-606.

Hulting, F.L., Orr, D.B. \& Obrycki, J.J. (1990) A computer program for calculation and statistical comparison of intrinsic rates of increase and associated life table parameters. Florida Entomologist 73, 601-612.

Kossou, D.K., Mareck, J.H. \& Bosque-Pérez, N.A. (1993) Comparison of improved and local maize varieties in the Republic of Benin with emphasis on susceptibility to Sitophilus zeamais Motschulsky. Journal of Stored Products Research 29, 333-343.

Meikle, W.G., Adda, C., Azoma, K., Borgemeister, C., Degbey, P., Djomamou, B. \& Markham, R.H. (1998) The effects of maize variety on the density of Prostephanus truncatus (Coleoptera: Bostrichidae) and Sitophilus zeamais (Coleoptera: Curculionidae) in post-harvest stores in Benin Republic. Journal of Stored Products Research 34, 45-58.

Moyal, P. (1988) Les foreurs du maïs en zone des savanes en Côte d'Ivoire. Collection Etudes et Thèses. ORSTOM, Paris, France.

Moyal, P. \& Tran, M. (1991a) Cob borer Mussidia nigrivenella (Lepidoptera; Pyralidae) of maize in Ivory Coast. I. Morphological and biological data. Insect Science and its Application 12, 209-214.

Moyal, P. \& Tran, M. (1991b) Cob borer Mussidia nigrivenella (Lepidoptera; Pyralidae) of maize in Ivory Coast. II. Ecological data. Insect Science and its Application 12, 215-223.

Osei-Bonsu, P., Buckles, D., Soza, F.R. \& Asibwo, J.Y. (1996) Edible cover crops. ILEA Newsletter for Ecologically Sound Agriculture 12, 30-31.

Ramasubramanian, G.V. \& Babu, P.C.S. (1989) Comparative biology of the spotted pod borer, Maruca testulalis (Geyer) on three host plants. Legume Research 12, 177-178.

Sankeperumal, G., Baskaran, S. \& Mohandoss, A. (1989) Influence of host plants on the organic constituents and fecundity of Spodoptera litura (Fabricius) (Lepidoptera: Noctuidae). Proceedings of the Indian National Science Academy Part B, Biological Sciences 55, 393-396.

Sétamou, M. (1996) Ecology of the insect pests of maize with special reference to Mussidia nigrivenella (Lepidoptera: Pyralidae) and the interaction with the aflatoxin producing fungus Aspergillus flavus. MSc thesis, University of Cape Coast, Ghana.

Sétamou, M., Cardwell, K.F., Schulthess, F. \& Hell, K. (1998) Effect of insect damage to maize ears, with special reference to Mussidia nigrivenella (Lepidoptera: Pyralidae), on Aspergillus flavus (Deuteromycetes: Monoliales) infection and aflatoxin production in maize before harvest in the Republic of Benin. Journal of Economic Entomology 91, 433-438. 
Sétamou, M., Schulthess, F., Bosque-Pérez, N.A. \& Thomas-Odjo, A. (1993) Effect of plant nitrogen and silica on the bionomics of Sesamia calamistis (Lepidoptera: Noctuidae). Bulletin of Entomological Research 83, 405411

Shanower, T., Schulthess, F. \& Gounou, S. (1991) Distribution and abundance of some stem and cob borers in Benin. Plant Health Management Research Monograph 1. International Institute of Tropical Agriculture, Ibadan, Nigeria.

Silvie, P. (1993) Nouvelles données sur Mussidia nigrivenella Ragonot (Lepidoptera: Pyralidae) au Togo. Insect Science and its Application 14, 643-649.

Sokal, R.R. \& Rohlf, J.F. (1992) Biometry. 2nd edn. 859 pp. New York, USA, W.H. Freeman.

Southwood, T.R.E. (1966) Ecological methods. 391 pp. Methuen \& Co.

Udedibie, A.B.I. (1990) Nutritional evaluation of jackbean (Canavalia ensiformis) for the Nigeria poultry industry. AMBIO 19, 361-365.
Vanderzant, E.S. (1974) Development, significance, and application of artificial diets for insects. Annual Review of Entomology 19, 139-160.

Vissoh, P., Manyong. V.M., Carsky, J.R., Osei-Bonsu, P. \& Galiba, M. (1998) Experiences with Mucuna in West Africa. pp. 128-141 in Buckles, D., Eteka, A., Osiname, O., Galiba, M. \& Galiano, N. (Eds) Cover crops in West Africa: contributing to sustainable agriculture. International Development Research Centre (IDRC), Ottawa, Canada.

Whitney, W.K. (1970) Observations on maize insects at the International Institute of Tropical Agriculture (IITA) Ibadan. Bulletin of the Entomological Society of Nigeria 2, 101-108.

Zar, J.H. (1974) Biostatistical analysis. 657 pp. New Jersey, USA, Prentice-Hall.

(Accepted 1 September 1999) (C) CAB International, 1999 


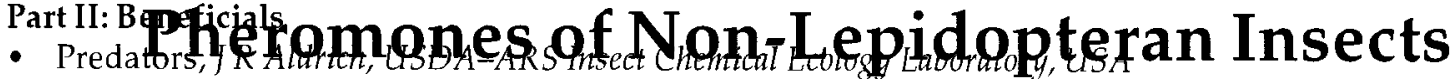

- Parasitoids, YKainoh, University of Jukubar, Ippan A gricultural Plants

- Bees, I Pettis, USDA-ARS, Honey Bee Research LaboraDry, USA, T Pankiw, University of California, USA and

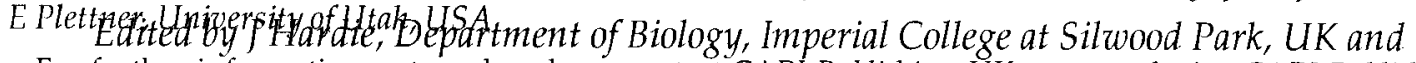
For further information Rr Minks, distribútor in your area.

September 1999. 480 padgesse ad $\mathrm{HB}^{2} .50$ per book postage and packing (excluding $U K$ ).

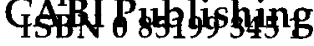

CAB.bP ubsishiagofAB International, Wallingford, Oxon OX10 8DE, UK

Tel: +44 (0)1491832111 Fax: +44 (0)1491 829292 Email: orders@cabi.org

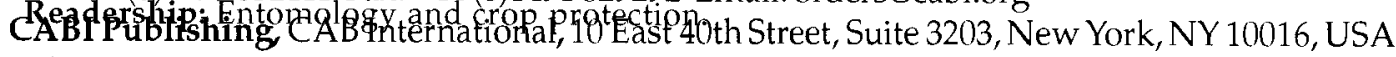

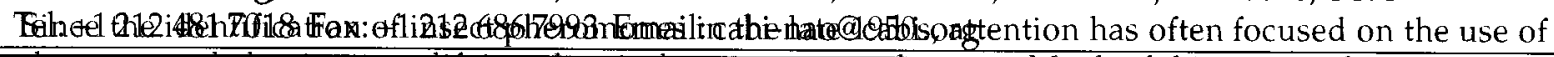
these potent behaviour-modityng chemicals as pest control agents. ivuch of tins interest has concentrated 3451 on Lepidoptera, particularly moths.

In addressing this topic in other insect orders, this multi-author book fills this current gap in the literature. It presents research from leading authorities on the most important insect groups, and details the current progress of research in these areas. Applications of the research to agricultural systems around the world, and possible mechanisms for sustainable crop protection, are considered.

This book is essential reading for students and researchers in entomology and crop protection.

Contents:

Part I: Pests

- Fruit Flies, PJ Landolt, USDA-ARS, Yakima Agricultural Research Laboratory, USA and A L Averill, University of Massachusetts, USA

- Gall Midges, M O Harris and S P Foster, The Horticulture and Food Research Institute of New Zealand Ltd, New Zealand

- Scarab Beetles, W Soares Leal, National Institute of Sericultural and Entomological Science, Japan

- Sap Beetles, R J Bartelt, USDA-ARS, National Center for Agricultural Utilization Research, USA

- Weevils, $R$ J Bartelt

- Forest Beetles, F Schlyter, Swedish Agricultural University, Sweden and G A Birgersson, Göteborg University, Sweden

- Stored-product Beetles, R Plarre, BAM-Federal Institute of Materials Research and Testing, Germany and $D C$ Vanderwel, University of Winnipeg, Canada

- Sawflies and Seed Wasps, O Anderbrant, Lund University, Sweden

- Aphids, J Hardie, J A Pickett, E M Pow and D W M Smiley, IACR-Rothamsted, UK

- Scale Insects, E Dunkelblum, Agricultural Research Organisation, Israel

- Phytophagous Bugs, H L McBrien and I G Millar, University of California, USA

- Grasshoppers and Locusts, A Hassanali and B Torto, International Centre of Insect Physiology and Ecology (ICIPE), Kenya 